\title{
Tricobezoar, síndrome de Rapunzel
}

\author{
Trichobezoar, Rapunzel syndrome
}

\section{Andrés Calderón, Alirio Rodrigo Bastidas• Bogotá, D.C. (Colombia)}

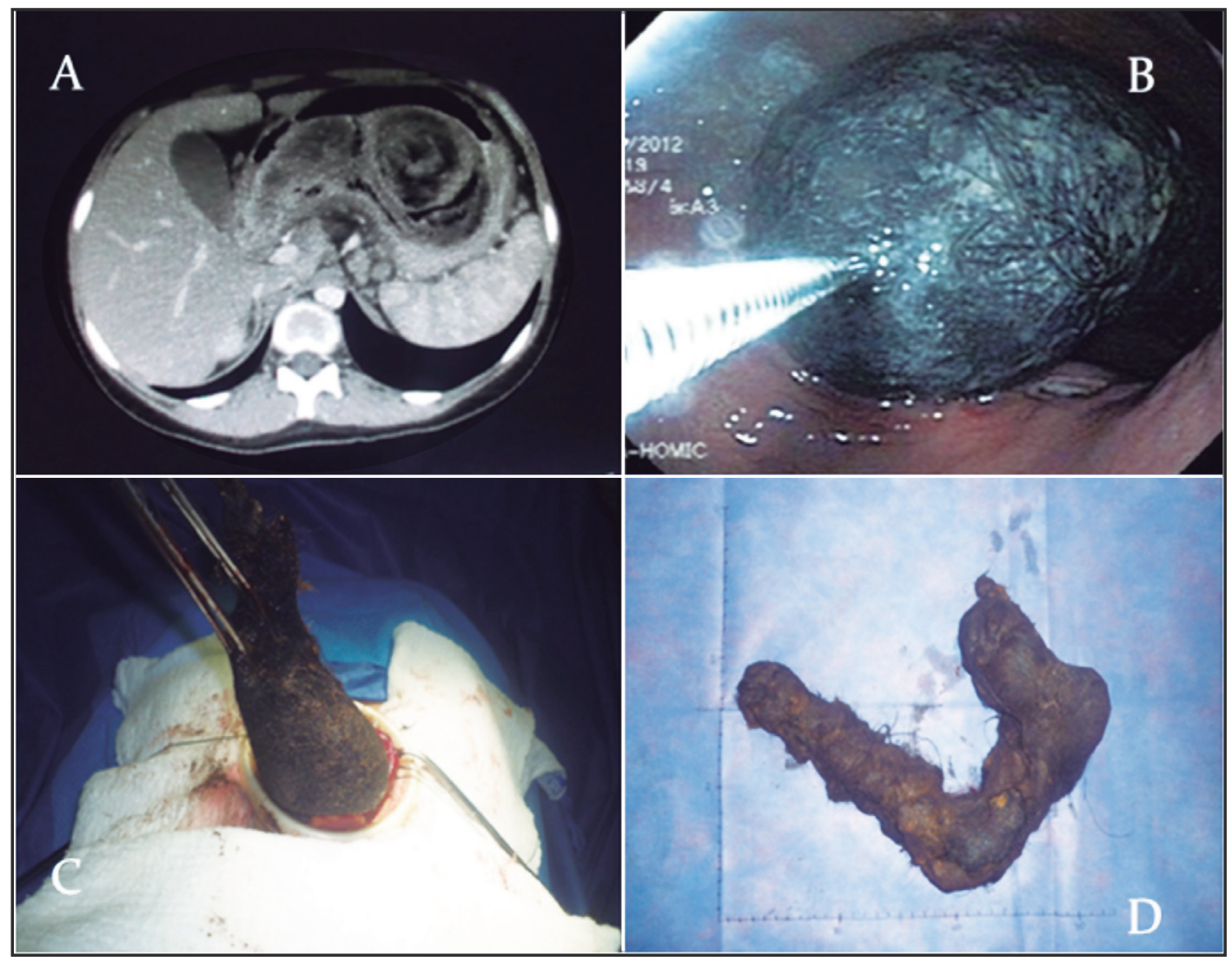

Figura 1. A: imagen tomográfica abdominal de tricobezoar en cámara gástrica, B: visualización de tricobezoar en endoscopia de vías digestivas altas, C: extracción quirúrgica de tricobezoar por gastrectomía, D: Imagen quirúrgica de tricobezoar.

Se presentan las imágenes de una adolescente de 15 años de edad con dolor abdominal de un mes de evolución, localizado en región meso y epigástrica, sin respuesta al tratamiento con inhibidor bomba de protones ni analgésico oral durante 20 días, asociado disnea, astenia y náuseas, anemia microcítica hipocrómica con requirimiento de transfusión. Se documenta perturbación emocional derivada de convivencia en hogar disfuncional. Tomografía abdominal simple y con contraste describe masa de densidad heterogénea con dimensiones de $117 \mathrm{~mm}$ x $67 \mathrm{~mm}$, desplazamiento esplénico posterior y de la cámara gástrica hacia

Dr. Andrés Calderón Ávila: Residente de II año Medicina Interna, Universidad Militar Nueva Granada, Hospital Militar Central; Dr. Alirio Rodrigo Bastidas Goyes: Internista, Neumólgo, Maestría Epidemiología, Hospital Militar Central, Universidad de la Sabana. Bogotá, D.C. (Colombia).

Correspondencia. Dr. Alirio Rodrigo Bastidas Goyes

E-mail: aliriorodrigo@yahoo.com

Recibido: 2/II/2014 Aceptado: 23/II/2015 arriba y adelante con disminución volumen intraluminal (imagen A). En endoscopia de vías digestivas altas se aprecia tricobezoar el cual ocupa el $70 \%$ de la cámara gástrica, múltiples ulceraciones aproximadamente de $8 \mathrm{~mm}$ en mucosa de cuerpo y antro cubiertas por fibrina (imagen B). Extracción quirúrgica de tricobezoar a través de gastrectomia anterior (imagen $\mathrm{C}$ ). Pieza quirúrgica de tricobezoar (imagen D), paciente egresa sin complicación e inicia apoyo interdisciplinario psicológico y psiquiátrico.

\section{Bibliiografía}

1. Ouazzani A, Bataille D, Dryjski J, Lefebvre JC, Guérin E, Vaneukem P. [Iron deficiency anaemia, pancreatitis and epigastric mass in a young female: a rare presentation of a large gastric trichobezoar]. Rev Med Brux 2009 Jan-Feb;30(1):47-51.

2. Shulutko AM, Agadzhanov VG, Kazaryan AM. Minilaparotomy removal of giant gastric trichobezoar in a female teenager. Medscape J Med 2008;10(9):220.

3. Vila S, García C, Piscoya A, de los Ríos R, Pinto JL, Huerta-Mercado J, Bussalleu A. Giant gastroduodenal trichobezoar: Rapunzel syndrome. Am J Gastroenterol 2009 Nov; 104(11):2864-5. 